\title{
Liquidity Constraints, the Extended Family, and Consumption
}

HwaJung Choi, Kathleen McGarry, and Robert F. Schoeni

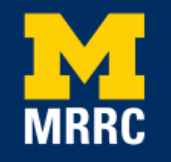

Project \#: UM14-04 


\title{
Liquidity Constraints, the Extended Family, and Consumption
}

\author{
HwaJung Choi \\ University of Michigan \\ Kathleen McGarry \\ University of California, Los Angeles \\ Robert F. Schoeni \\ University of Michigan \\ May 2015 \\ Michigan Retirement Research Center \\ University of Michigan \\ P.O. Box 1248 \\ Ann Arbor, MI 48104 \\ www.mrrc.isr.umich.edu \\ (734) 615-0422
}

\section{Acknowledgements}

The research reported herein was performed pursuant to a grant from the U.S. Social Security Administration (SSA) funded as part of the Retirement Research Consortium through the University of Michigan Retirement Research (Grant \# 2 RRC08098401-06-00). The opinions and conclusions expressed are solely those of the author(s) and do not represent the opinions or policy of SSA or any agency of the Federal Government. Neither the United States Government nor any agency thereof, nor any of their employees, makes any warranty, express or implied, or assumes any legal liability or responsibility for the accuracy, completeness, or usefulness of the contents of this report. Reference herein to any specific commercial product, process or service by trade name, trademark, manufacturer, or otherwise does not necessarily constitute or imply endorsement, recommendation or favoring by the United States Government or any agency thereof.

\section{Regents of the University of Michigan}

Michael J. Behm, Grand Blanc; Mark J. Bernstein, Ann Arbor; Laurence B. Deitch, Bloomfield Hills; Shauna Ryder Diggs, Grosse Pointe; Denise Ilitch, Bingham Farms; Andrea Fischer Newman, Ann Arbor; Andrew C. Richner, Grosse Pointe Park; Katherine E. White, Ann Arbor; Mark S. Schlissel, ex officio 


\title{
Liquidity Constraints, the Extended Family, and Consumption
}

\begin{abstract}
This study examines whether the extended family influences consumption. Extending prior tests on food consumption to total consumption, little to no evidence is found in support of altruism among related households and or that fluctuations in dynastic income affects one's own consumption. However, the effect of transitory fluctuations in own income on consumption are contingent on own wealth and the wealth of the extended family, with estimates of the marginal propensity to consume roughly three times higher for individuals whose own and extended family wealth is low versus individuals whose own and extended family wealth is high.
\end{abstract}

\section{Citation}

Choi, HwaJung, Kathleen McGarry, and Robert F. Schoeni. "Liquidity Constraints, the Extended Family, and Consumption." University of Michigan Retirement Research Center (MRRC) Working Paper, WP 2015-320. Ann Arbor, MI.

http://www.mrrc.isr.umich.edu/publications/papers/pdf/wp320.pdf

\section{Authors’ Acknowledgements}

The research reported herein was pursuant to a grant from the U.S. Social Security Administration (SSA), funded as part of the Retirement Research Consortium (RRC). The findings and conclusions expressed are solely those of the authors and do not represent the views of SSA, any agency of the federal government, or the University of Michigan. 
Empirical studies estimating the marginal propensity to consume out of income have focused recently on heterogeneity across consumers. Specifically, consistent with theory (Jappelli and Pistaferri, 2010), researchers have concluded that consumers facing liquidity constraints spend a greater share of their transitory income relative to other consumers (Kaplan, Violante, and Weidner, 2014; Zeldes, 1989; Browning and Crossley, 2001; Jappelli and Pistaferri, 2014; Johnson, Parker, and Souleles, 2006). These findings have important ramifications for public policy because policies that increase (or decrease) family income would have a larger effect on the macro economy if consumers facing liquidity constraints were the ones who experienced increases in their income.

A distinct literature has examined the extent to which the economic decisions of extended family members are interconnected. In particular, this literature has tested the hypothesis that income of extended family members, e.g., parents of grown children, affects the consumption decisions of grown children even if parents and adult children live in separate households. Altonji, Hayashi, and Kotlikoff (AHK, 1992) is the most influential study of this type, where they find that income of extended family members may have a small effect on food consumption.

We integrate these two literatures by extending models estimating the marginal propensity to consume out of income to include the role of the extended family. In particular, we estimate a model where consumers' decisions may be influenced by members of their extended family and where some family members, but perhaps not others, have limited wealth. The model implies that the marginal propensity to consume out of a consumer's own income is affected not only by whether that consumer (e.g., adult child) has few liquid assets, but by whether their extended family (e.g., parent) has few liquid assets. Specifically, the marginal propensity to 
consume should be the highest when both the consumer and their extended family have few liquid assets.

Before we test these predictions, we update and extend the empirical tests conducted by AHK. AHK was limited by the fact that in the data set that allowed them to examine dynastic models — the Panel Study of Income Dynamics (PSID) through 1985 — the only consumption category that could be analyzed was food. We take advantage of the fact that the PSID subsequently significantly expanded the measurement of consumption, allowing us to study a nearly comprehensive measure of consumption. Having more expansive data on consumption is important because the effects of (own) income on food consumption are small relative to the effects on other components of consumption, and therefore AHK's conclusions that the income of the extended family has limited effects on food consumption may not characterize effects on total consumption.

\section{Data}

The Panel Study of Income Dynamics (PSID) has been used extensively to study consumption expenditures of American families, but almost all of these studies are restricted to expenditure data on food and housing, which have been measured in the PSID in nearly every wave since 1968. The PSID expanded measures of consumption expenditures significantly in 1999, and again in 2005. With the new questions, the PSID captured roughly 70 percent of expenditures between 1999 and 2003 (food, housing, utilities, vehicles, transportation, health care, education, and child care) and 95 percent of expenditures 2005 through 2011 (the prior list plus clothing and apparel, home repairs and maintenance, household furnishings and equipment, recreation and entertainment, and trips and vacations). Furthermore, estimates of spending based on the PSID 
align well with the best cross-sectional survey data, the Consumer Expenditure Survey (Li et al., 2010; Andreski et al., 2014). Our analyses are restricted to data from 1999 through 2011 to take advantage of the more expensive consumption data. The full set of items analyzed is described in detail by Andreski et al. (2013). We report models for two time periods: 1999-2011 with the more limited set of measures, and 2005-2011 with the more expansive measures.

The PSID has two additional strengths. First, when children of PSID sample members leave a PSID household they are followed by the survey. As a result, parents and adult children are each themselves interviewed. Second, the PSID contains detailed information on income, wealth, and consumption.

Our baseline sample consists of all PSID heads and wives ages 24 and older who have in the same survey year — at least one non-co-resident relative (specifically, a biological mother, father, or child, or a half or full sibling) who is also a head or wife and at least 24 years old. The number of such individuals in each year is reported in Table 1. For example, in 2011 there were 7,612 such individuals, 5,207 were heads and 2,405 were wives. These individuals lived in 6,719 different PSID households (in PSID language, “family units”), and represented 1,504 distinct family dynasties (in PSID language, “distinct 1,968 IDs”).

Our analysis sample size varies depending on the analytic model estimated because of missing values in specific measures and model specifications. For example, we use the log transformation for income and consumption, therefore cases with zero values of income ( $0.8 \%)$ or consumption (about 1.4 percent) are dropped. The analysis sample that includes more complete expenditure measures is limited to the years of 2005-2011. To test life-cycle model, we include lagged variables (t-2 and t-4) of nonasset family/dynasty income, which results in 
missing values for those who recently entered PSID or recently qualified under our baseline analysis sample criteria.

We consider two different definitions of dynasty, one including only close relatives i.e., "narrow dynasty" — and one including relatives of any kind - i.e., "broad dynasty.” The narrow dynasty includes one's biological mother, father, child, and full/half siblings who are also PSID heads or wives ages 24 and older and do not live in the same PSID family unit as that individual. An individual's dynasty members can change over time as some family members become age 24 and older, or a head or wife during the sample period, and because step-siblings may change due to divorce or marriage by parents. Moreover, the dynasty structure is not necessarily hierarchical; dynasty composition of a focal person may differ from the dynasty composition of a fellow dynasty member. Potential sources of such cases include in-law relationships, remarriage, grandchildren, and grandparents. For example, suppose a focal person has a mother and a biological child in his dynasty. However, the mother of the focal person does not include the child (i.e., her grandchild) in her dynasty per our definition of dynasty. Another example is the case of husbands and wives; a focal person has his wife and his biological parents in his dynasty but does not have parents-in-law, while his wife includes them in her dynasty. Therefore, the couple can have different composition of dynasty members while they themselves are members of each other's dynasty. About half of the sample members are not nested within the dynasty (i.e., a focal person's dynasty composition is not the same as the dynasty composition of at least one member in the focal person's dynasty). We also estimated models using a broader definition of dynasty where anyone in the same PSID "1968 ID” is defined as being members of the same dynasty. Our substantive findings did not change and, therefore, we do not report estimates using the broad definition. 
For some empirical models we include dynasty fixed-effects. In these models we restrict the sample to individuals within dynasties where all members of a given dynasty share the exact same dynasty members, i.e., individuals are fully nested within dynasties. Appendix Table A1 summarizes frequencies by the number of a person's dynasty members whose dynasty members are not identical to the person's.

Dynasty income and wealth is the average among family units that contain members of a given dynasty, excluding one's own family unit income and wealth. For example, if a woman lives by herself, her biological parents live together, and her son and daughter are 24 and older and live independently, her average dynasty income is the average family unit income among three PSID family units: her parents', her son's, and her daughter’s. ${ }^{1}$

It is not clear whether AHK included the value of food stamps in their measure of food consumption. Therefore, we use two consumption measures of food: excluding food stamps and including food stamps. The Consumer Price Index for All Urban Consumers (CPI-U) was applied for the price adjustment for income, wealth, and consumption, expressed in 2011 dollars. Descriptive statistics for all variables for each analysis sample are summarized in Table 2. Also in Table 2 are descriptive statistics for all individuals 24 and older, regardless of whether they are a head or wife or have at least one non-co-resident biological mother, father, child, or full/half sibling who is also a head or wife 24 or older (i.e., our baseline sample). We find that the socioeconomic composition is quite similar in the two samples.

\footnotetext{
${ }^{1}$ AHK include one's own income and wealth in the calculation of dynasty income and wealth when testing the life-cycle model; therefore, we report estimates in appendix table A2 using their approach for comparison.
} 


\section{Testing altruism and life-cycle models}

The altruism model implies that own resources have no effect on own consumption once dynasty resources are controlled (AHK, 1992). The life-cycle model, on the other hand, predicts that own resources influence own consumption. We test these predictions using AHK's econometric approach but with more expansive consumption and wealth data in recent waves of the PSID.

Altruism. The econometric model used for the static test of altruism is:

$$
c_{i k}=\beta^{\prime} X_{i k}+\varphi Y_{i k}+\alpha_{i}+\mu_{i k}
$$

where $c_{i k}$ is $\log$ consumption (i.e., food 1999-2011; total 1999-2011; total, expanded 2005-2011) by household $k$ of dynasty $i, X_{i k}$ are demographic control variables (quadratic in the number of members in own household and average number of members of households within one's dynasty, own age and age of household head, own gender and the gender of household head, race of household head, marital status of household head), $Y_{i k}$ is log total household income excluding private transfers, $\alpha_{i}$ is the dynasty fixed effect and $\mu_{i k}$ is the error term that is assumed to be uncorrelated with $Y$. All years of data are pooled, and we include year indicators as control variables.

The dynamic test is the first difference of (1):

$$
\Delta c_{i k t}=\beta^{\prime} \Delta X_{i k t}+\varphi \Delta Y_{i k t}+\Delta \alpha_{i t}+\Delta \mu_{i k t}
$$

Standard errors for both models are White standard errors, allowing for clustering at the yeardynasty level. Because the PSID has surveyed every two years since 1997, the first difference in our analysis is the difference between year $\mathrm{t}$ and year $\mathrm{t}-2$.

Households are not stable units over time. For example, when a couple divorces the household splits. In such cases, analyzing changes in "households" is problematic. Some studies address this challenge by restricting analyses to households that have little or no demographic 
change, for example, households in which there is no marriage or divorce. A limitation of this approach is that changes in family structure are important events that should be considered. Therefore, we use a different approach. Throughout our analyses, adults (specifically, PSID heads and wives) in a given year are the units of analysis. This allows us to follow adults as they change households and examine their household consumption.

To compare our results with AHK's, we begin by modeling food consumption, but for the years of data on which we focus, 1999 - 2011 (Table 3). For the static models, we find that own income has a sizable effect, with an elasticity of 0.290 when the dynasty fixed effect is not included but we restrict to individuals in nested dynasties, very similar to AHK's estimate of 0.286 (Table 3, row 1, in brackets). Not restricting to nested dynasties leads to a very similar estimate, 0.303. Adding fixed effects lowers the income effect to 0.240 , which is the same as AHK (0.240; their Table 3, row 1).

The dynamic test implies a substantially lower but still statistically significant effect: 0.075 without dynasty fixed effects and 0.090 with the fixed effects. Our dynamic estimates are smaller than AHK's.

Including the amount of food stamps as food spending lowers the effect of income. This pattern is expected because only low-income households are eligible for food stamps and food consumption from food stamps is not as sensitive to income changes. However, the effect of own income remains statistically significant and substantial.

As expected, income has a larger effect on the broader measures of consumption than it has on food alone. First consider consumption (excluding food stamps) that is consistently measured from 1999-2011. For these categories of spending, the income effect in the dynamic fixed effect specification is 0.100 for total consumption versus 0.090 for food consumption only. 
The most inclusive measure of consumption, available 2005-2011, has an income effect of 0.128 in the dynamic fixed effect model. In sum, regardless of specification, income has a substantial, statistically significant effect on consumption, which is inconsistent with altruism.

Life-cycle model. The static test of the life-cycle model consists of regressing log consumption on log household income (excluding private transfers and asset income) for time $t$ and lagged two periods, log average dynasty income (excluding private transfers and asset income) for time $t$ and lagged two periods, household wealth without home equity at time $t$, and average dynasty wealth without home equity at time $t$. We use the inverse hyperbolic sine transformation on wealth because a substantial share of families has zero or negative wealth. Control variables include a quadratic in the number of members in own household and average number of members of households within one's dynasty, own age and age of household head, own gender and the gender of household head, race of household head, marital status of household head, and year indicators. The life-cycle model predicts that the dynasty income effect is zero.

Estimates from the static model implies a substantial effect of own income on food consumption including food stamps, with a total effect (i.e., the sum of current and two lagged effects) equal to 0.239 (Table 4). The estimate of dynasty income is 0.047 and statistically significant. $^{2}$

The effects of own income and dynasty income are larger for the more expansive measures of consumption. When food stamps are included, for food, total consumption (1999_

\footnotetext{
${ }^{2}$ Comparisons with AHK are not strictly parallel because they use annual data and lagged income measured at $t-1$ and $t-2$ instead of $t-2$ and $t-4$. Furthermore, AHK includes own income (wealth) in dynasty income (wealth). In Table A2 we re-estimate the models reported in table 4 by using AHK's definition of dynasty income and wealth. Compared to AHK's estimates, our estimates in table A2 are somewhat greater.
} 
2011), and total expanded consumption (2005-2011), the own income effect (dynasty income effect) is 0.239 (0.047), $0.462(0.071)$, and 0.501 (0.078), respectively.

Given the substantial difference in estimates when more categories of consumption are considered, Table 5 reports estimates for each of the main spending categories. A substantial share of families has no spending in some categories in a given year; therefore we estimate three different models: log consumption dropping observations without positive spending in a given category, log consumption dropping observations that do not have positive spending in all of the categories reported in Table 5 (i.e., balanced sample), and a linear probability model of having any spending in the given category. For all three approaches, own and dynasty income effects are smaller for food consumption than for almost all of the other seven consumption categories. The effects are especially large for trips and vacations: 0.656 and 0.167 for own and dynasty consumption, respectively. Vacations are particularly interesting because family members often experience them together. If one's parents' income increases, then the parents may purchase a longer or more expensive vacation. If they share vacation with their children, they may also pay for some of their adult children's vacation. Alternatively, in order to satisfy their parents' desire for a more expensive joint vacation, the adult children may also increase vacation expenditures even if their own income is unchanged.

The dynamic test of the life-cycle model consists of estimating the econometric model where change in log consumption is the dependent variable and change in log own income and change in log average dynasty income are the key explanatory variables. Control factors include year indicators and changes in the demographic factors (i.e., quadratic in the number of members in own household and average number of members of households within one's dynasty, own age and age of household head, own gender and the gender of household head, race of household 
head, marital status of household head). We estimate models of change over two years and four years. For two-year change, we find estimates of own income on food of 0.049 when food stamps are included (table 6). As expected, own income effects are larger when consumption on additional items is considered: 0.093 for the most comprehensive measure of consumption. The estimates based on four-year change are larger than those based on two-year change. For example, the estimate for the most comprehensive measure of consumption is 0.136 versus 0.093 .

The dynamic tests with four-year change imply marginally significant but meaningful effects of dynasty income on own food consumption and the more comprehensive measure of consumption available 1999 - 2011. For food consumption including food stamps, the dynasty effect is 0.011 , which is roughly one-seventh the size of the effect of own income, 0.070 . The more comprehensive measure available for 1999-2011 has a similar dynasty effect $-0.010-$ and is roughly one-tenth the size of the effect of own income. For the most comprehensive measure of consumption, available 2005 - 2011, the dynasty effect is 0.014 , also roughly onetenth the size of the effect of own income, 0.136 . However, with roughly half the sample size, this effect is not statistically significant. In sum, we interpret the collection of estimates from the static and dynamic models as indicating suggestive evidence of an effect of dynastic income on one's own consumption.

\section{Marginal propensity to consume and dynastic liquidity constraints}

The updated and extended tests of AHK provide little to no support for the strict altruism model and fairly strong evidence for the life-cycle model. In this section we extend our investigation of the life-cycle model by testing for heterogeneity in the marginal propensity to 
consume out of transitory income. Recent literature has demonstrated that the transitory income effect varies by liquid wealth holdings, with much larger effects among households with little or no liquid wealth (Kaplan et al., 2014; Zeldes, 1989; Browning and Crossley, 2001; Jappelli and Pistaferri, 2014; Johnson, et al. 2006).

The extended family is thought to be one of the most important sources of credit and insurance. Therefore, we test the hypothesis that the magnitude of transitory income effects are contingent on own wealth and wealth of the extended family.

To estimate the transitory income effect on consumption, we use the approach of Blundell, Pistaferri, and Preston (2008), Kaplan and Violante (2010), and Kaplan, Violante, and Weidner (2014). First, we regress log household income and log consumption (food, total 1999 2011, and total expanded 2005 - 2011) on age (quartic), education $(<12,12,>12)$, race (white, black, others), family unit size (one, two, three, four, five+), marital status of head (married, not married), employment status (employed, not employed), region (six categories), year indicators, and interactions between the year indicators and education, race, employment, and region. From this model, we calculate the residuals of log consumption and log income. We then regress the change in the residuals of log consumption on the change in residuals of log income, but instrument change in the residuals of log income at time $t$ with residuals of log income at time $t+2$.

We stratified these models by liquid (i.e., non-housing) wealth and average liquid wealth of dynasty members excluding one’s own liquid wealth. We use wealth measured in 1999 to determine wealth status. For those who entered the analysis sample after 1999, we use the wealth measure that was first observed. Theory provides only limited guidance on exactly how the magnitude of the marginal propensity to consume differs across levels of liquid wealth. 
Therefore, our choice of wealth categories is driven largely by available sample size to detect differential effects. Separately for own liquid wealth and for extended family average liquid wealth, we identify three groups: below the $25^{\text {th }}$ percentile, $25-75^{\text {th }}$ percentile, and greater than the $75^{\text {th }}$ percentile. The $25^{\text {th }}$ percentile for own liquid wealth (extended family average liquid wealth) is $\$ 6(\$ 2,300)$. The 75 th percentile of own liquid wealth (extended family average liquid wealth) is $\$ 79,217$ (\$84,557). Cross-classifying household wealth by extended family wealth generates nine categories for which the transitory income effect is estimated. The size of each of the nine groups is reported in Table A3.

There is a strong correlation in wealth holdings of parents and adult children (Charles and Hurst, 2003). However, there remains a substantial share of adult children with low wealth whose parents have significant wealth holdings. Among households in the bottom quartile of the 1998-2011 sample, 54 percent are members of dynasties whose wealth is in the middle 50 percent and 19 percent in the top quartile (Table A3).

Before estimating models stratified by wealth, we estimate the effect of transitory income for the full sample, but separately for the different consumption measures. Transitory income effects are much larger for total consumption than for food consumption: 0.089 versus 0.039 when food stamps are included (Table 7).

The estimates of the marginal propensity to consume - by own wealth and dynasty wealth - are reported in Table 8. The last column in each panel reports estimates by own wealth regardless of dynasty wealth. The pattern of estimates is generally consistent with prior findings, with substantial and statistically significant effects among the bottom two categories of own wealth but no significant effect among individuals in the top quartile of the own wealth 
distribution. For the most part, this pattern holds regardless of the measure of consumption analyzed.

Consistent with the predictions based on theory, among individuals in the bottom own wealth category, the estimates of the marginal propensity to consume out of transitory income are qualitatively larger if dynasty wealth is in one of the bottom two groups. For example, in the middle panels where consumption measured from 1999 through 2011 is examined, the marginal propensity to consume for low-wealth families (bottom 25 percent), whose dynasty wealth is in the bottom two categories, ranges from 0.108 to 0.143 . In two of the four cases the marginal propensity to consume is statistically significant at the 0.05 level, but it is -0.02 and insignificant for the highest category of dynasty wealth. This pattern also exists when the broadest measure of consumption is examined (i.e. the bottom panels), although the point estimates are not statistically significant.

The estimates of the marginal propensity to consume among individuals in the middle or top of the own-wealth distribution are less consistent with predictions. Among individuals in the middle of the own-wealth distribution, the estimates of the marginal propensity to consume are not larger for individuals whose dynasty wealth is low. In fact, the statistically significant effects among the middle-wealth category are among individuals whose dynasty wealth is in the middle or top category.

\section{Discussion}

The recent economic downturn has refocused attention on the role of the family in providing protection against economic shocks. The media is replete with stories of older parents helping adult children cope with unemployment, perhaps to the detriment of their own retirement 
and savings plans. This assistance is not limited to transfers from parents to adult children but can also flow from children to parents, a potentially important phenomenon as layoffs in the last recession hit older workers particularly hard. Assistance can take many forms, including cash, in-kind gifts, and time help. Furthermore, even if assistance is not received, knowing that the extended family is available if needed may affect behavior.

As the national population ages and programs such as Social Security come under increasing financial pressure, understanding the role of families in providing support for their members becomes increasingly important. Furthermore, to the extent that support of adult children affects the savings and labor market behavior of older workers, older parents may find their own futures negatively affected by shocks to the incomes of their children. And children hit hard in their peak earning years may be unable to provide for elderly parents.

Despite widespread anecdotal evidence of beneficence, empirical tests have rejected altruism as a motivation for behavior. Many of these tests have relied on the relationship between changes in incomes of parents and children and changes in family transfers (Cox, 1987, Altonji et al., 1997). However, economic models also suggest that individuals save in order to smooth consumption and cope with declines in income. A negative shock need not necessitate assistance from family if individuals have their own wealth holdings or have access to credit. A more rigorous test would be based on changes in consumption. However, because of the paucity of consumption data in national surveys, studies examining the role of family in smoothing consumption are rare. Altonji et al.'s widely cited study uses data on food consumption in the PSID to test whether resources are shared fully within families. They examine the effect of own income on consumption controlling for extended-family fixed effects, and strongly reject strict altruism and, furthermore, find limited to no evidence that changes in 
dynastic income leads to changes in food consumption 1968-1985. Our estimates using comprehensive information on consumption from 1999-2011 imply similar qualitative conclusions about altruism; we reject the predictions of the strict altruism model. However, the estimates from the static and dynamic models taken together imply suggestive evidence in favor of effects of dynastic income on own consumption.

We go on to test whether the response of own consumption to changes in transitory income is dependent on not only one's own wealth, but the wealth of the extended family. We find some evidence indicating that the effect of transitory income on consumption is influenced by the level of wealth held by extended family members. 


\section{References}

Altonji, J.G., F. Hayashi, and L. Kotlikoff. 1992. "Is the Extended Family Altruistically Linked? Direct Evidence Using Micro Data.” American Economic Review 82(5):1177-1198.

Altonji, J.G., F. Hayashi, and L. Kotlikoff. 1997. "Parental Altruism and Inter Vivos Transfers: Theory and Evidence.” Journal of Political Economy 105(6): 1121-1166.

Andreski, P., G. Li, MZ. Samancioglu, \& R. Schoeni. 2014. "Estimates of annual consumption expenditures and its major components in the PSID in comparison to the CE.” American Economic Review: Papers and Proceedings. May

Blundell, R., L. Pistaferri, and I. Preston. 2008. “Consumption inequality and partial insurance.” American Economic Review, 98(5): 1887-1921.

Browning, M., and T.F. Crossley. 2001. “Unemployment insurance benefit levels and consumption changes.” Journal of Public Economics 80(1): 1-23.

Charles, K.K., and E. Hurst. 2003. “The Correlation of Wealth across Generations.” Journal of Political Economy 111(6): 1155-1182.

Cox, D. 1987.“Motives for Private Income Transfers.” Journal of Political Economy 95(3): 509546.

Jappelli, T. and L. Pistaferri. 2010. “The consumption response to income changes.” Annual Review of Economics 2: 479-506.

Jappelli, T., and L. Pistaferri. 2014. “Fiscal policy and MPC heterogeneity.” American Economic Journal: Macroeconomics 6(4): 107-36.

Johnson, D.S., J.A. Parker, and N.S. Souleles. 2006. “Household Expenditure and the Income Tax Rebates of 2001.” American Economic Review 96: 1589-1610 
Kaplan, G., G. Violante, and J. Weidner. 2014. “The wealthy hand-to-mouth.” Brookings Panel on Economic Activity.

Kaplan, G., and G. Violante. 2010. "How Much Consumption Insurance Beyond SelfInsurance?” American Economic Journal: Macroeconomics 2(4): 53-87.

Li, G., R.F. Schoeni, S. Danziger, and K.K. Charles. 2010. “New Expenditure Data in the PSID: Comparisons with the CE.” Monthly Labor Review 133(2): 29-39.

McGarry, K. 2012. “Dynamic Aspects of Family Transfers.” NBER working paper 18446.

Zeldes, S. 1989. "Consumption and liquidity constraints: an empirical investigation.” Journal of Political Economy 97: 305-46. 


\begin{tabular}{|c|c|c|c|c|c|c|c|c|c|c|}
\hline \multicolumn{11}{|c|}{ Table 1. Number of individuals, PSID family units, and dynasties } \\
\hline & & & & & & & & & & \\
\hline & \multicolumn{5}{|c|}{$\begin{array}{l}\text { Analytic sample without restricting to nested dynasties (Baseline } \\
\text { sample) }\end{array}$} & \multicolumn{5}{|c|}{ All individuals 24 and older } \\
\hline & $\begin{array}{l}\text { Number of } \\
\text { individuals } \\
\text { (unit of } \\
\text { analysis) }\end{array}$ & $\begin{array}{c}\text { Number of } \\
\text { heads }\end{array}$ & $\begin{array}{c}\begin{array}{c}\text { Number of } \\
\text { wives }\end{array} \\
\end{array}$ & $\begin{array}{c}\begin{array}{c}\text { Number of } \\
\text { PSID family } \\
\text { units }\end{array} \\
\end{array}$ & $\begin{array}{c}\text { Number of } \\
\text { dynasties }\end{array}$ & $\begin{array}{l}\text { Number of } \\
\text { individuals } \\
\text { (unit of } \\
\text { analysis) }\end{array}$ & $\begin{array}{c}\text { Number of } \\
\text { heads }\end{array}$ & $\begin{array}{c}\text { Number of } \\
\text { wives }\end{array}$ & $\begin{array}{c}\begin{array}{c}\text { Number of } \\
\text { PSID family } \\
\text { units }\end{array} \\
\end{array}$ & $\begin{array}{c}\text { Number of } \\
\text { dynasties }\end{array}$ \\
\hline 1999 & 5310 & 3523 & 1787 & 4696 & 1326 & 11687 & 6795 & 3840 & 6691 & 2490 \\
\hline 2001 & 5686 & 3758 & 1928 & 5031 & 1359 & 12318 & 7168 & 4065 & 7079 & 2426 \\
\hline 2003 & 6106 & 4083 & 2023 & 5403 & 1414 & 13014 & 7612 & 4169 & 7490 & 2393 \\
\hline 2005 & 6594 & 4396 & 2198 & 5817 & 1452 & 13469 & 7806 & 4331 & 7665 & 2347 \\
\hline 2007 & 6879 & 4613 & 2266 & 6053 & 1473 & 13905 & 8102 & 4454 & 7909 & 2278 \\
\hline 2009 & 7380 & 4995 & 2385 & 6496 & 1517 & 14594 & 8514 & 4599 & 8335 & 2244 \\
\hline 2011 & 7612 & 5207 & 2405 & 6719 & 1504 & 14887 & 8735 & 4594 & 8549 & 2190 \\
\hline Total & 45567 & 30575 & 14992 & 40215 & 10045 & 93874 & 54732 & 30052 & 53718 & 16368 \\
\hline
\end{tabular}

Analytic sample: heads and wives 24 and older who have - in the same year - at least one non-coresident biological mother, father, child, or full/half sibling who is also a head or wife 24 or older. 


\begin{tabular}{|c|c|c|c|c|}
\hline \multicolumn{5}{|c|}{ Table 2. Descriptive statistics } \\
\hline & & $\begin{array}{l}\text { Nested dynasty } \\
\text { sample }\end{array}$ & $\begin{array}{c}\text { Baseline analysis } \\
\text { sample }\end{array}$ & $\begin{array}{c}\text { All individuals } \\
>=24\end{array}$ \\
\hline Characteristic & Statistic & $\mathrm{N}=23314$ & $\mathrm{~N}=45567$ & $\mathrm{~N}=93874$ \\
\hline Age & mean (years) & 48.4 & 47.1 & 45.3 \\
\hline Female & $\%$ & 54.8 & 55.6 & 53.6 \\
\hline \multicolumn{5}{|l|}{ Race of head } \\
\hline White & $\%$ & 68.9 & 65.8 & 62.2 \\
\hline Black & $\%$ & 26.5 & 30.8 & 30.9 \\
\hline Others & $\%$ & 4.6 & 3.4 & 6.9 \\
\hline \multicolumn{5}{|l|}{ Marital status of head } \\
\hline Married or permanently cohabiting & $\%$ & 70.4 & 64.7 & 67.1 \\
\hline Single, never legally married & $\%$ & 12.6 & 15.7 & 12.7 \\
\hline Widowed & $\%$ & 4.9 & 5.5 & 5.7 \\
\hline Divorced & $\%$ & 9.4 & 10.9 & 10.2 \\
\hline Separated & $\%$ & 2.7 & 3.2 & 4.3 \\
\hline Number of family members & q25; q50; q75 & $2 ; 2 ; 4$ & $2 ; 2 ; 4$ & $2 ; 3 ; 4$ \\
\hline \multicolumn{5}{|l|}{ Annual family consumption } \\
\hline Food (without foodstamp) & median $(\$)$ & 6240 & 5720 & 6160 \\
\hline Foodstamp & $>0$; median $\$$ among & $7 \% ; 2400$ & $9 \% ; 2532$ & $10 \% ; 2760$ \\
\hline Total consumption & median $(\$)$ & 31131 & 29637 & 31047 \\
\hline Total consumption/\# in FU & median (\$) & 12748 & 12584 & 11651 \\
\hline Total consumption 2005-2011 & median (\$) & 41516 & 38000 & 40033 \\
\hline Total consumption/\# in FU 2005-2011 & median (\$) & 17032 & 16285 & 15072 \\
\hline \multicolumn{5}{|l|}{ Annual family income } \\
\hline Family Income without transfer & median (\$) & 56108 & 51000 & 52706 \\
\hline Per capita Family Income without transfer & median (\$) & 22950 & 21683 & 19733 \\
\hline Family non-asset income & median (\$) & 54600 & 50000 & 51600 \\
\hline \multicolumn{5}{|l|}{ Annual narrow dynasty income } \\
\hline N. of families per dynasty & q10; q50; q90 & $2 ; 4 ; 7$ & $2 ; 3 ; 6$ & \\
\hline Average narrow dynasty income (per family) & median (\$) & 61323 & 58180 & \\
\hline Average expansive dynasty non-asset income (per family) & median (\$) & 59147 & 56067 & \\
\hline \multicolumn{5}{|l|}{ Family wealth } \\
\hline Family wealth without equity & median (\$) & 27000 & 18000 & 16000 \\
\hline Per capita Family wealth without equity & median (\$) & 10500 & 7300 & 5700 \\
\hline Family wealth with equity & median (\$) & 83000 & 57800 & 52000 \\
\hline Per capita Family wealth with equity & median (\$) & 32075 & 23000 & 18339 \\
\hline \multicolumn{5}{|l|}{ Narrow dynasty wealth } \\
\hline N. of families per dynasty & q10; q50; q90 & $2 ; 3 ; 5$ & $2 ; 3 ; 6$ & \\
\hline Average narrow dynasty wealth without equity (per family) & median $(\$)$ & 48880 & 41683 & \\
\hline Average narrow dynasty wealth with equity (per family) & median (\$) & 106734 & 92225 & \\
\hline
\end{tabular}


Table 3. Tests of altruism: Effects of own income on consumption

\begin{tabular}{|c|c|c|c|c|c|c|c|c|c|c|}
\hline & & & & & & & & & & \\
\hline & \multicolumn{5}{|c|}{ Static test } & \multicolumn{5}{|c|}{ Dynamic test } \\
\hline & \multicolumn{2}{|c|}{ Baseline sample } & \multicolumn{3}{|c|}{ Restricted to nested dynasty sample } & \multicolumn{2}{|c|}{ Baseline sample } & \multicolumn{3}{|c|}{ Restricted to nested dynasty sample } \\
\hline & $\begin{array}{c}\text { No dynasty fixed } \\
\text { effect }\end{array}$ & $\begin{array}{c}\text { Sample } \\
\text { size }\end{array}$ & $\begin{array}{l}\text { No dynasty fixed } \\
\text { effect }\end{array}$ & \begin{tabular}{|c|}
$\begin{array}{c}\text { Dynasty fixed } \\
\text { effect }\end{array}$ \\
\end{tabular} & $\begin{array}{c}\text { Sample } \\
\text { size }\end{array}$ & $\begin{array}{l}\text { No dynasty fixed } \\
\text { effect }\end{array}$ & $\begin{array}{c}\text { Sample } \\
\text { size }\end{array}$ & $\begin{array}{l}\text { No dynasty fixed } \\
\text { effect }\end{array}$ & $\begin{array}{c}\text { Dynasty fixed } \\
\text { effect }\end{array}$ & $\begin{array}{c}\text { Sample } \\
\text { size }\end{array}$ \\
\hline \multirow[t]{2}{*}{$\begin{array}{l}\text { Food 1999-2011, excluding food } \\
\text { stamps }\end{array}$} & $0.303^{* * *}$ & 44085 & $0.290 * * *$ & $0.240 * * *$ & 22677 & $0.084 * * *$ & 32813 & $0.075^{* * *}$ & $0.090^{* * *}$ & 16349 \\
\hline & & & {$[0.286 \mathrm{t}=33.07]$} & {$[0.240 \mathrm{t}=23.29]$} & 23257 & & & [0.144 t=13.35] & [0.137 t=10.43] & 15439 \\
\hline & & & & & & & & & & \\
\hline $\begin{array}{l}\text { Food 1999-2011, including food } \\
\text { stamps }\end{array}$ & $0.204^{* * *}$ & 44481 & $0.212^{* * *}$ & $0.170^{* * *}$ & 22826 & $0.050 * * *$ & 33254 & $0.054^{* * *}$ & $0.056^{* * *}$ & 16501 \\
\hline & & & & & & & & & & \\
\hline $\begin{array}{l}\text { Total consumption 1999-2011, } \\
\text { excluding food stamps }\end{array}$ & $0.424 * * *$ & 44632 & $0.418 * * *$ & $0.358 * * *$ & 22895 & $0.090^{* * *}$ & 33454 & $0.099 * * *$ & $0.100^{* * *}$ & 16588 \\
\hline & & & & & & & & & & \\
\hline $\begin{array}{l}\text { Total consumption 1999-2011, } \\
\text { including food stamps }\end{array}$ & $0.389 * * *$ & 44611 & $0.391 * * *$ & $0.332 * * *$ & 22883 & $0.075^{* * *}$ & 33419 & $0.086 * * *$ & $0.084 * * *$ & 16570 \\
\hline & & & & & & & & & & \\
\hline & & & & & & & & & & \\
\hline $\begin{array}{l}\text { Total consumption, expanded, 2005- } \\
\text { 2011, excluding food stamps }\end{array}$ & $0.459 * * *$ & 28026 & $0.461^{* * *}$ & $0.405^{* * *}$ & 12878 & $0.112 * * *$ & 18455 & $0.126 * * *$ & $0.128 * * *$ & 8236 \\
\hline & & & & & & & & & & \\
\hline $\begin{array}{l}\text { Total consumption, expanded, 2005- } \\
\text { 2011, including food stamps }\end{array}$ & $0.424 * * *$ & 28003 & $0.433 * * *$ & $0.378 * * *$ & 12865 & $0.098 * * *$ & 18422 & $0.113^{* * *}$ & $0.110^{* * *}$ & 8217 \\
\hline
\end{tabular}

AHK's estimates reported in brackets and are from table 3 in their manuscript. AHK dynamic tests are for two-year difference to parellel our two-year differences.

$*, * *, * * *$ indicates statistical significance at the $0.05,0.01$, and 0.001 level, respectively.

Control variables included in all models: quadratics in the number of members in own household and average number of members of households within one's dynasty, own age and age of household head, own gender and the gender of household head, race of household head, marital status of household head, year dummies. 
Table 4. Static tests of life cycle model: Effects of own and dynasty resources on consumption

\begin{tabular}{|c|c|c|c|c|c|c|}
\hline & $\begin{array}{l}\text { Food 1999- } \\
\text { 2011, excluding } \\
\text { food stamps }\end{array}$ & $\begin{array}{l}\text { Food 1999- } \\
\text { 2011, including } \\
\text { food stamps }\end{array}$ & $\begin{array}{c}\text { consumption } \\
\text { 1999-2011, } \\
\text { excluding food }\end{array}$ & $\begin{array}{l}\text { consumption } \\
\text { 1999-2011, } \\
\text { including food }\end{array}$ & $\begin{array}{c}\text { consumption, } \\
\text { expanded, 2005- } \\
\text { 2011, excluding } \\
\end{array}$ & $\begin{array}{c}\text { consumption, } \\
\text { expanded, 2005- } \\
\text { 2011, including } \\
\end{array}$ \\
\hline & $\mathrm{N}=28509$ & $\mathrm{~N}=28493$ & $\mathrm{~N}=28509$ & $\mathrm{~N}=28493$ & $\mathrm{~N}=18912$ & $\mathrm{~N}=18899$ \\
\hline \multicolumn{7}{|l|}{ Own income } \\
\hline $\mathrm{t}$ & $0.197 * * *$ & $0.122 * * *$ & $0.247 * * *$ & $0.226 * * *$ & $0.267 * * *$ & $0.247 * * *$ \\
\hline $\mathrm{t}-2$ & $0.076^{* * *}$ & $0.062 * * *$ & $0.129 * * *$ & $0.126^{* * *}$ & $0.135 * * *$ & $0.130 * * *$ \\
\hline $\mathrm{t}-4$ & $0.067 * * *$ & $0.055 * * *$ & $0.112 * * *$ & $0.109 * * *$ & $0.125 * * *$ & $0.124 * * *$ \\
\hline ihs own wealth time $t$ & $0.003^{* * *}$ & $0.002^{* * *}$ & $0.002^{* * *}$ & $0.002^{* * *}$ & $0.003^{* * *}$ & $0.003^{* * *}$ \\
\hline \multicolumn{7}{|l|}{ Dynasty income } \\
\hline $\mathrm{t}$ & $0.041^{* * *}$ & $0.031 * * *$ & $0.040 * * *$ & $0.038 * * *$ & $0.053 * * *$ & $0.050 * * *$ \\
\hline $\mathrm{t}-2$ & 0.007 & 0.008 & $0.014 *$ & $0.015^{*}$ & 0.007 & 0.008 \\
\hline $\mathrm{t}-4$ & $0.019 *$ & 0.008 & $0.022^{* * *}$ & $0.018^{* *}$ & $0.024 * *$ & $0.020 * *$ \\
\hline ihs dynasty wealth time t & -0.001 & $-0.002 * *$ & $-0.001+$ & $-0.001^{*}$ & -0.001 & $-0.001+$ \\
\hline \multicolumn{7}{|l|}{ Sum of income coefficients } \\
\hline Own & $0.340 * * *$ & $0.239 * * *$ & $0.488 * * *$ & $0.462^{* * *}$ & $0.526^{* * *}$ & $0.501^{* * *}$ \\
\hline Dynasty & $0.066^{* * *}$ & $0.047 * * *$ & $0.076 * * *$ & $0.071^{* * *}$ & $0.083^{* * *}$ & $0.078 * * *$ \\
\hline \multicolumn{7}{|c|}{ 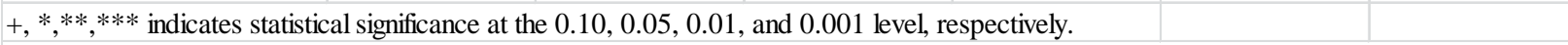 } \\
\hline \multicolumn{7}{|c|}{$\begin{array}{l}\text { Control variables included in all models: quadratics in the number of members in own household and average number of members of } \\
\text { households within one's dynasty, own age and age of household head, own gender and the gender of household head, race of household head, } \\
\text { marital status of household head, year dummies. }\end{array}$} \\
\hline ihs=inverse hyperbolic sin & ansformation. & & & & & \\
\hline
\end{tabular}


Table 5. Static tests of life cycle model: Effects of own and dynasty resources on consumption Disaggregated consumption

\begin{tabular}{|c|c|c|c|c|c|c|c|c|}
\hline & $\begin{array}{l}\text { Food 1999- } \\
\text { 2011, including } \\
\text { food stamps } \\
\end{array}$ & $\begin{array}{c}\text { Utilities, 1999- } \\
2011 \\
\end{array}$ & \begin{tabular}{|c|} 
Vehicle gas, 1999 \\
2011 \\
\end{tabular} & $\begin{array}{c}\text { Health care, } 1999 . \\
2011 \\
\end{array}$ & $\begin{array}{c}\text { Clothing, 2005- } \\
2011 \\
\end{array}$ & $\begin{array}{c}\text { Household } \\
\text { repairs, 2005- } \\
2011 \\
\end{array}$ & $\begin{array}{c}\text { Household } \\
\text { furnishings, 2005- } \\
2011 \\
\end{array}$ & $\begin{array}{c}\text { Trip/vacations, } \\
\text { 2005-2011 } \\
\end{array}$ \\
\hline \multicolumn{9}{|c|}{\begin{tabular}{|l|l|} 
Drop observations with no consumption in given category & \\
\end{tabular}} \\
\hline & $\mathrm{N}=28493$ & $\mathrm{~N}=27038$ & $\mathrm{~N}=25485$ & $\mathrm{~N}=26559$ & $\mathrm{~N}=17886$ & $\mathrm{~N}=11321$ & $\mathrm{~N}=12054$ & $\mathrm{~N}=12662$ \\
\hline \multicolumn{9}{|c|}{ Sum of income coefficients } \\
\hline Own & $0.239 * * *$ & $0.169 * * *$ & $0.272^{* * *}$ & $0.440^{* * *}$ & $0.577 * * *$ & $0.536 * * *$ & $0.478 * * *$ & $0.656^{* * *}$ \\
\hline Dynasty & $0.047 * * *$ & $-0.030 * * *$ & $-0.044 * * *$ & $0.124 * * *$ & $0.097 * * *$ & $0.061^{*}$ & $0.041+$ & $0.167 * * *$ \\
\hline \multicolumn{9}{|c|}{ Drop observations with no consumption in any of the given categories (i.e., balanced panel, 2005-2011) } \\
\hline & $\mathrm{N}=6342$ & $\mathrm{~N}=6342$ & $\mathrm{~N}=6342$ & $\mathrm{~N}=6342$ & $\mathrm{~N}=6342$ & $\mathrm{~N}=6342$ & $\mathrm{~N}=6342$ & $\mathrm{~N}=6342$ \\
\hline \multicolumn{9}{|c|}{ Sum of income coefficients } \\
\hline Own & $0.278 * * *$ & $0.219 * * *$ & $0.254 * * *$ & $0.292 * * *$ & $0.637 * * *$ & $0.575 * * *$ & $0.516 * * *$ & $0.667 * * *$ \\
\hline Dynasty & $0.037 * * *$ & 0.003 & $-0.056 * *$ & $0.049+$ & $0.097 * * *$ & 0.038 & 0.038 & $0.178 * * *$ \\
\hline \multicolumn{9}{|c|}{ Linear probability model of whether any spending (i.e., 0/1) } \\
\hline & na & $\mathrm{N}=28509$ & $\mathrm{~N}=28509$ & $\mathrm{~N}=28509$ & $\mathrm{~N}=18912$ & $\mathrm{~N}=18912$ & $\mathrm{~N}=18912$ & $\mathrm{~N}=18912$ \\
\hline \multicolumn{9}{|c|}{ Sum of income coefficients } \\
\hline Own & na & $0.046^{* * *}$ & $0.087 * * *$ & $0.079 * * *$ & $0.043^{* * *}$ & $0.156^{* * *}$ & $0.103 * * *$ & $0.190 * * *$ \\
\hline Dynasty & na & 0.000 & $0.014^{* * *}$ & $0.020 * * *$ & 0.002 & $0.018 * *$ & $0.012+$ & $0.057 * * *$ \\
\hline$+, *, * *, * * *$ & es statistical signif & ance at the 0.10 , & $0.05,0.01$, and 0.0 & 01 level, respective & & & & \\
\hline \multicolumn{9}{|c|}{$\begin{array}{l}\text { Control variables included in all models: quadratics in the number of members in own household and average number of members of households within one's dynasty, own } \\
\text { age and age of household head, own gender and the gender of household head, race of household head, marital status of household head, year dummies. }\end{array}$} \\
\hline na=Not app & because all obser & ations have positi & e food consumption & & & & & \\
\hline
\end{tabular}


Table 6. Dynamic tests of the life cycle model: Effects of change in own and dynasty resources on change in consumption

\begin{tabular}{|l|c|c|c|c|c|c|}
\hline & $\begin{array}{c}\text { Food 1999- } \\
\text { 2011, excluding } \\
\text { food stamps }\end{array}$ & $\begin{array}{c}\text { Food 1999- } \\
\text { 2011, including } \\
\text { food stamps }\end{array}$ & $\begin{array}{c}\text { consumption } \\
\text { 1999-2011, } \\
\text { excluding food }\end{array}$ & $\begin{array}{c}\text { consumption } \\
\text { 1999-2011, } \\
\text { including food }\end{array}$ & $\begin{array}{c}\text { consumption, } \\
\text { expanded, 2005. expanded, 2005 } \\
\text { 2011, excluding }\end{array}$ & $\begin{array}{c}\text { consumption, } \\
\text { 2011, including }\end{array}$ \\
\hline $\mathrm{t}-(\mathrm{t}-2)$ & $\mathrm{N}=30718$ & $\mathrm{~N}=30852$ & $\mathrm{~N}=30948$ & $\mathrm{~N}=30913$ & $\mathrm{~N}=17867$ & $\mathrm{~N}=17837$ \\
\hline Change in own income & $0.085^{* * *}$ & $0.049^{* * *}$ & $0.084^{* * *}$ & $0.070^{* * *}$ & $0.107^{* * *}$ & $0.093^{* * *}$ \\
\hline Change in dynasty income & 0.008 & 0.004 & 0.005 & 0.005 & 0.005 & 0.004 \\
\hline $\mathrm{t}-(\mathrm{t}-4)$ & $\mathrm{N}=23611$ & $\mathrm{~N}=23713$ & $\mathrm{~N}=23777$ & $\mathrm{~N}=23758$ & $\mathrm{~N}=11064$ & $\mathrm{~N}=11052$ \\
\hline Change in own income & $0.120^{* * *}$ & $0.070^{* * *}$ & $0.129^{* * *}$ & $0.112^{* * *}$ & $0.155^{* * *}$ & $0.136^{* * *}$ \\
\hline Change in dynasty income & $0.013+$ & $0.011+$ & $0.011+$ & $0.010+$ & 0.014 & 0.014 \\
\hline
\end{tabular}

$+, *, * *, * * *$ indicates statistical significance at the $0.10,0.05,0.01$, and 0.001 level, respectively.

Control variables included in all models: quadratics in the number of members in own household and average number of members of households within one's dynasty, own age and age of household head, own gender and the gender of

household head, race of household head, marital status of household head, year dummies. 
Table 7. Marginal propensity to consume out of transitory income shocks

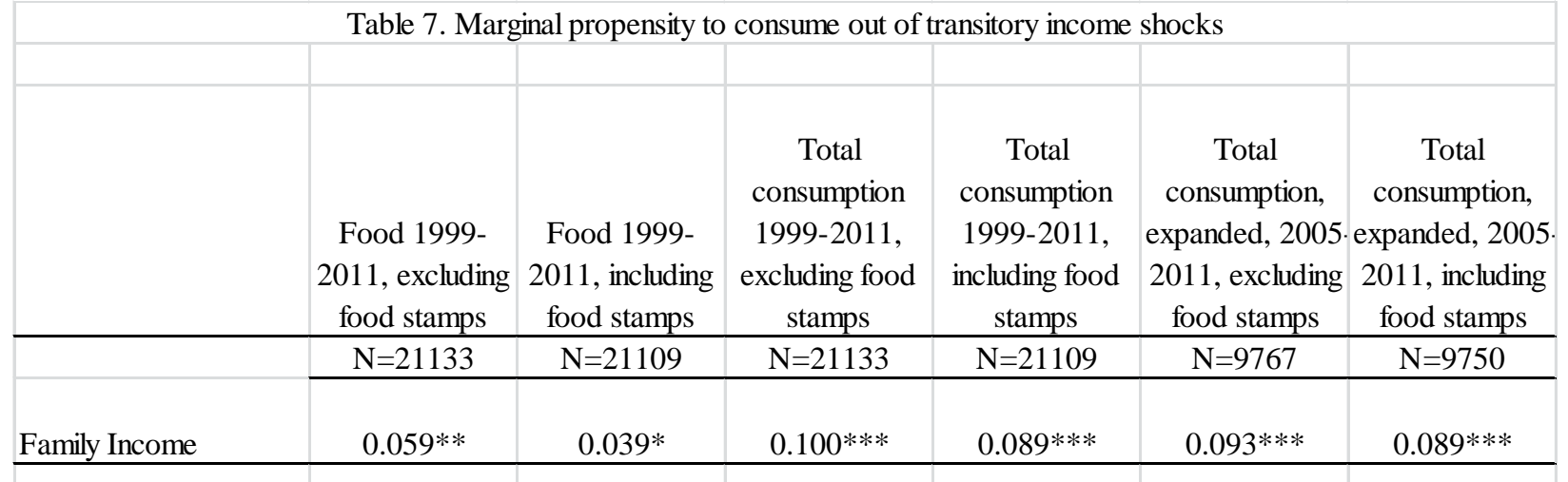

$*, * *, * * *$ indicates statistical significance at the $0.05,0.01$, and 0.001 level, respectively. 
Table 8. Marginal propensity to consume out of transitory income shocks by wealth category

\begin{tabular}{|l|l|c|c|c|c|}
\hline \multicolumn{7}{|c|}{ Effect on food expenditure excluding food stamp } \\
\cline { 2 - 6 } & $\begin{array}{c}1999-2011 \\
\text { Sample }\end{array}$ & Bottom 25\% & $25-75 \%$ & Top 25\% & \multirow{2}{*}{} \\
\hline \multirow{2}{*}{$\begin{array}{l}\text { Own family } \\
\text { wealth }\end{array}$} & Bottom 25\% & 0.074 & $0.159^{*}$ & -0.002 & $0.099^{*}$ \\
& $25-75 \%$ & 0.025 & 0.054 & $0.115^{*}$ & $0.063^{*}$ \\
\cline { 2 - 6 } & Top 25\% & -0.084 & -0.02 & 0.007 & -0.017 \\
\hline
\end{tabular}

\begin{tabular}{|l|l|c|c|c|c|}
\hline \multicolumn{1}{|c|}{ Effect on food expenditure including food stamp } \\
\cline { 2 - 6 } & $\begin{array}{c}1999-2011 \\
\text { Sample }\end{array}$ & Bottom 25\% & $25-75 \%$ & Top 25\% & \\
\hline \multirow{2}{*}{$\begin{array}{l}\text { Own family } \\
\text { wealth }\end{array}$} & \begin{tabular}{l} 
Bottom 25\% \\
\cline { 2 - 6 }
\end{tabular} & 0.019 & $0.091+$ & -0.001 & 0.053 \\
\cline { 2 - 6 } & Top 25\% & -0.006 & $0.053+$ & $0.106^{*}$ & $0.053^{*}$ \\
\hline
\end{tabular}

Effect on total consumption excluding food stamp (using 1999-2011 sample)

\begin{tabular}{|l|l|c|c|c|c|}
\hline \multirow{5}{*}{} & \multicolumn{5}{|c|}{ (using 1999-2011 sample) } \\
\cline { 2 - 6 } & $\begin{array}{c}1999-2011 \\
\text { Sample }\end{array}$ & Bottom 25\% & $25-75 \%$ & Top 25\% & \\
\hline \multirow{2}{*}{$\begin{array}{l}\text { Own family } \\
\text { wealth }\end{array}$} & Bottom 25\% & 0.108 & $0.143^{* *}$ & -0.02 & $0.102^{* * *}$ \\
& $25-75 \%$ & $0.082+$ & $0.152^{* * *}$ & $0.154^{* * *}$ & $0.133^{* * *}$ \\
& Top 25\% & -0.001 & 0.062 & -0.011 & 0.022 \\
\hline
\end{tabular}

\begin{tabular}{|c|c|c|c|c|c|}
\hline \multicolumn{6}{|c|}{$\begin{array}{l}\text { Effect on total consumption excluding food stamp } \\
\text { (using 2005-2011 sample) }\end{array}$} \\
\hline & & \multicolumn{3}{|c|}{ Dynasty wealth (excluding one's own wealth) } & \\
\hline & $\begin{array}{l}\text { 2005-2011 } \\
\text { Sample }\end{array}$ & Bottom 25\% & $25-75 \%$ & Top 25\% & \\
\hline \multirow{3}{*}{$\begin{array}{l}\text { Own family } \\
\text { wealth }\end{array}$} & Bottom 25\% & 0.111 & 0.107 & -0.009 & 0.087 \\
\hline & $25-75 \%$ & 0.021 & $0.196 * * *$ & $0.193^{* *}$ & $0.152^{* * *}$ \\
\hline & Top 25\% & $-0.256^{*}$ & $0.180^{*}$ & $0.136+$ & 0.083 \\
\hline
\end{tabular}

\begin{tabular}{|c|c|c|c|c|c|}
\hline \multicolumn{6}{|c|}{$\begin{array}{l}\text { Effect on total consumption including food stamp } \\
\text { (using 1999-2011 sample) }\end{array}$} \\
\hline & & \multicolumn{3}{|c|}{ Dynasty wealth (excluding one's own wealth) } & \\
\hline & $\begin{array}{c}1999-2011 \\
\text { Sample }\end{array}$ & Bottom 25\% & $25-75 \%$ & Top 25\% & \\
\hline \multirow{3}{*}{$\begin{array}{l}\text { Own family } \\
\text { wealth }\end{array}$} & Bottom 25\% & $0.111+$ & $0.116^{* *}$ & -0.021 & $0.086^{* *}$ \\
\hline & $25-75 \%$ & 0.059 & $0.140^{* * *}$ & $0.153^{* * *}$ & $0.122^{* * *}$ \\
\hline & Top 25\% & -0.006 & 0.063 & -0.011 & 0.022 \\
\hline
\end{tabular}

\begin{tabular}{|l|l|c|c|c|c|}
\hline \multicolumn{7}{|c|}{$\begin{array}{c}\text { Effect on total consumption including food stamp } \\
\text { (using 2005-2011 sample) }\end{array}$} \\
\cline { 2 - 6 } & $\begin{array}{c}\text { 2005-2011 } \\
\text { Sample }\end{array}$ & Bottom 25\% & $25-75 \%$ & Top 25\% & \\
\hline \multirow{2}{*}{$\begin{array}{l}\text { Own family } \\
\text { wealth }\end{array}$} & $\begin{array}{l}\text { Bottom 25\% } \\
\text { Dynasty wealth (excluding one's own wealth) }\end{array}$ & 0.098 & $0.107+$ & -0.008 & 0.082 \\
\hline & $25-75 \%$ & 0.006 & $0.184^{* * *}$ & $0.190^{* *}$ & $0.141^{* * *}$ \\
\hline
\end{tabular}

$+, *, * *, * * *$ indicates statistical significance at the $0.10,0.05,0.01$, and 0.001 level, respectively. 


\begin{tabular}{|c|c|c|c|c|c|c|}
\hline \multicolumn{7}{|c|}{ Table A1. Number of individuals in nested dynasties, for selected years } \\
\hline \multicolumn{7}{|c|}{ Analytic sample without restricting to individuals in nested dynasties } \\
\hline & \multicolumn{2}{|c|}{ Year 1999} & \multicolumn{2}{|c|}{ Year 2005} & \multicolumn{2}{|c|}{ Year 2011} \\
\hline $\begin{array}{l}\text { \# of person i's dynasty } \\
\text { members whose dynasty } \\
\text { members are not identical to i's }\end{array}$ & $\begin{array}{c}\text { \# of } \\
\text { persons }\end{array}$ & $\%$ & $\begin{array}{c}\text { \# of } \\
\text { persons }\end{array}$ & $\%$ & $\begin{array}{c}\text { \# of } \\
\text { persons }\end{array}$ & $\%$ \\
\hline 0 & 3469 & 65.33 & 3315 & 50.27 & 3294 & 43.27 \\
\hline 1 & 939 & 17.68 & 1782 & 27.02 & 2434 & 31.98 \\
\hline 2 & 524 & 9.87 & 610 & 9.25 & 639 & 8.39 \\
\hline 3 & 160 & 3.01 & 325 & 4.93 & 387 & 5.08 \\
\hline 4 & 89 & 1.68 & 196 & 2.97 & 312 & 4.1 \\
\hline 5 & 55 & 1.04 & 156 & 2.37 & 222 & 2.92 \\
\hline 6 & 33 & 0.62 & 103 & 1.56 & 139 & 1.83 \\
\hline 7 & 16 & 0.3 & 42 & 0.64 & 78 & 1.02 \\
\hline 8 & 15 & 0.28 & 35 & 0.53 & 48 & 0.63 \\
\hline 9 & 4 & 0.08 & 18 & 0.27 & 26 & 0.34 \\
\hline 10 & 4 & 0.08 & 5 & 0.08 & 19 & 0.25 \\
\hline 11 & 2 & 0.04 & 3 & 0.05 & 8 & 0.11 \\
\hline 12 & 0 & 0 & 1 & 0.02 & 5 & 0.07 \\
\hline 13 & 0 & 0.01 & 2 & 0.03 & 1 & 0.01 \\
\hline 14 & 0 & 0 & 1 & 0.02 & 0 & 0 \\
\hline Total & 5310 & 100.02 & 6594 & 100.01 & 7612 & 100 \\
\hline
\end{tabular}


Table A2. Static tests of life cycle model: Effects of own and dynasty resources on consumption INCLUDE own income (wealth) in dynasty income (wealth)

\begin{tabular}{|c|c|c|c|c|c|c|}
\hline & $\begin{array}{l}\text { Food 1999- } \\
2011, \\
\text { excluding food } \\
\text { stamps }\end{array}$ & $\begin{array}{l}\text { Food 1999- } \\
2011, \\
\text { including food } \\
\text { stamps }\end{array}$ & $\begin{array}{c}\text { Total } \\
\text { consumption } \\
\text { 1999-2011, } \\
\text { excluding food } \\
\text { stamps }\end{array}$ & $\begin{array}{c}\text { Total } \\
\text { consumption } \\
\text { 1999-2011, } \\
\text { including food } \\
\text { stamps }\end{array}$ & $\begin{array}{c}\text { Total } \\
\text { consumption, } \\
\text { expanded, } \\
\text { 2005-2011, } \\
\text { excluding food } \\
\text { stamps }\end{array}$ & $\begin{array}{c}\text { Total } \\
\text { consumption, } \\
\text { expanded, } \\
\text { 2005-2011, } \\
\text { including food } \\
\text { stamps }\end{array}$ \\
\hline & $\mathrm{N}=29318$ & $\mathrm{~N}=29302$ & $\mathrm{~N}=29318$ & $\mathrm{~N}=29302$ & $\mathrm{~N}=19247$ & $\mathrm{~N}=19234$ \\
\hline \multicolumn{7}{|l|}{ Own income } \\
\hline $\mathrm{t}$ & $0.178 * * *$ & $0.108 * * *$ & $0.224^{* * *}$ & $0.205^{* * *}$ & $0.237 * * *$ & $0.218 * * *$ \\
\hline$t-2$ & $0.071^{* * *}$ & $0.054 * * *$ & $0.119 * * *$ & $0.115^{* * *}$ & $0.123^{* * *}$ & $0.117^{* * *}$ \\
\hline $\mathrm{t}-4$ & $0.057 * * *$ & $0.047 * * *$ & $0.098 * * *$ & $0.097 * * *$ & $0.112^{* * *}$ & $0.112^{* * *}$ \\
\hline ihs own wealth time $t$ & $0.003^{* * *}$ & $0.002^{* * *}$ & $0.003^{* * *}$ & $0.002^{* * *}$ & $0.004^{* * *}$ & $0.004^{* * *}$ \\
\hline \multicolumn{7}{|l|}{ Dynasty income } \\
\hline $\mathrm{t}$ & $0.068^{* * *}$ & $0.053^{* * *}$ & $0.075^{* * *}$ & $0.072 * * *$ & $0.108 * * *$ & $0.103^{* * *}$ \\
\hline $\mathrm{t}-2$ & 0.016 & $0.022+$ & $0.031^{* *}$ & $0.033^{* *}$ & $0.026+$ & $0.030^{*}$ \\
\hline $\mathrm{t}-4$ & $0.028^{*}$ & $0.017+$ & $0.038 * * *$ & $0.034^{* * *}$ & $0.029 *$ & $0.025+$ \\
\hline ihs dynasty wealth time & 0 & $-0.001+$ & -0.001 & $-0.001+$ & -0.001 & -0.001 \\
\hline \multicolumn{7}{|c|}{ Sum of income coefficients } \\
\hline Own & $0.305^{* * *}$ & $0.209 * * *$ & $0.441^{* * *}$ & $0.416^{* * *}$ & $0.472 * * *$ & $0.448 * * *$ \\
\hline AHK estimate & {$[0.208 \mathrm{t}=13.97$} & & & & & \\
\hline Dynasty & $0.113^{* * *}$ & $0.093 * * *$ & $0.143 * * *$ & $0.139 * * *$ & $0.163^{* * *}$ & $0.157 * * *$ \\
\hline AHK estimate & {$[0.062 \mathrm{t}=3.04]$} & & & & & \\
\hline
\end{tabular}

AHK estimates reported in brackets and based on income measured at t, t-1, and t-2 and reported in their table 6. $+, *, * *, * * *$ indicates statistical significance at the $0.10,0.05,0.01$, and 0.001 level, respectively.

Control variables included in all models: quadratics in the number of members in own household and average number of members of households within one's dynasty, own age and age of household head, own gender and the gender of household head, race of household head, marital status of household head, year dummies.

ihs=inverse hyperbolic sine transformation. 
Table A3. Sample size (frequency) for sample stratified by own and extended family wealth

\begin{tabular}{|c|c|c|c|c|c|c|c|}
\hline \multicolumn{8}{|c|}{ 1999-2011 Sample } \\
\hline \multirow{5}{*}{$\begin{array}{l}\text { Own family } \\
\text { wealth }\end{array}$} & & \multicolumn{6}{|c|}{ Extended family wealth } \\
\hline & & \multicolumn{2}{|c|}{ Bottom 25\%: } & \multicolumn{2}{|c|}{ 25-75\%: } & \multicolumn{2}{|c|}{ Top 25\%: } \\
\hline & \multirow{2}{*}{ Bottom 25\% : } & 1108 & $(5.0 \%)$ & 2150 & $(9.6 \%)$ & 746 & $(3.3 \%)$ \\
\hline & & 2126 & (9.5\%) & 6343 & $(28.4 \%)$ & \multicolumn{2}{|c|}{2621 (11.7\%) } \\
\hline & Top 25\%: & 859 & $(3.8 \%)$ & \multicolumn{2}{|c|}{3179 (14.2\%) } & \multicolumn{2}{|c|}{$3227(14.4 \%)$} \\
\hline & & & & & & & \\
\hline \multicolumn{8}{|c|}{ 2005-2011 Sample - including more consumption items } \\
\hline & & \multicolumn{6}{|c|}{$\begin{array}{l}\text { Extended family wealth } \\
\end{array}$} \\
\hline & & \multicolumn{2}{|c|}{ Bottom 25\%: } & \multicolumn{2}{|c|}{ 25-75\%: } & \multicolumn{2}{|c|}{ Top 25\%: } \\
\hline \multirow{3}{*}{$\begin{array}{l}\text { Own family } \\
\text { wealth }\end{array}$} & Bottom 25\% : & \multicolumn{2}{|c|}{$579(5.9 \%)$} & \multicolumn{2}{|c|}{$1028(10.5 \%)$} & \multicolumn{2}{|c|}{374 (3.8\%) } \\
\hline & 25-75\%: & \multirow{2}{*}{\multicolumn{2}{|c|}{$1045(10.6 \%)$}} & \multirow{2}{*}{\multicolumn{2}{|c|}{$2726(27.7 \%)$}} & \multirow{2}{*}{\multicolumn{2}{|c|}{$\begin{array}{l}1168(11.9 \%) \\
1240(12.6 \%)\end{array}$}} \\
\hline & Top 25\%: & & & & & & \\
\hline
\end{tabular}

